\title{
Swimming against the Tide
}

The independent and uncoventional attitude of this journal is now well known to our readers. The publication of the 1997 impact factors of journals listed in the Science Citation Index by the Institute for Scientific Information seems to support our quest. Our impact factor of 1.80 places Psychotherapy and Psychosomatics in the top 10 psychological journals and at the 24th position in the psychiatry ranking. The progress of the journal is depicted by figure 1, which also shows how psychosomatic medicine is alive and well at the turn of the century by including the other 4 leading psychosomatic journals. Such psychoso- matic prominence is also supported by other psychosomatic journals which are included in the Science Citation Index (International Journal of Psychiatry in Medicine, Stress Medicine, Journal of Psychosomatic Obstetrics and Gynecology, Zeitschrift für Psychosomatische Medizin und Psychoanalyse). The journal's progress has been the result of the joint effort of several factors. One factor has certainly been the expert advice of our reviewers (such as the ones listed below who supplemented the Editorial Board during 1998). In 1998 we introduced a new policy in our review process. All reviewers are asked to disclose
F. Anagnastopoulos, Athens, Greece

D. Antonuccio, Reno, Nev., USA

J. Astin, Irvine, Calif., USA

M. Bach, Vienna, Austria

M. Bagby, Toronto, Ont., Canada

W. Baile, Houston, Tex., USA

M. Balestrieri, Udine, Italy

E. Becker, Dresden, Germany

H. Berenbaum, Champaign, Ill., USA

M.P. Borres, Goteborg, Sweden

M. Cazzaro, Padova, Italy

S. Conti, Bologna, Italy

R.J. Contrada, New Brunswick, N.J., USA

P. Copeland, Salem, Mass., USA

E. Corazziari, Roma, Italy

A. Costantini, Roma, Italy

F. Creed, Manchester, UK

T. Deckersbach, Boston, Mass., USA

R. Delle Chiaie, Roma, Italy

J.B. Drew, Columbus, Ohio, USA

L. Drummond, London, UK

H. Dupont, Lyon, France

F. Facchinetti, Modena, Italy

S. Faraone, Boston, Mass., USA

A. Favaro, Padova, Italy

E. Ferguson, Nottingham, UK
J. Fleury, Chapel Hill, N.C., USA

F. Frankel, Boston, Mass., USA

R. Fry, Uxbridge, UK

L. Grassi, Ferrara, Italy

M. Hengeveld, Leiden, The Netherlands

A. House, Leeds, UK

R.S. Jorgensen, Syracuse, N.Y., USA

H.S. Kaplan, Toronto, Ont., Canada

J. Kokkonen, Oulu, Finland

F. Lamprecht, Hannover, Germany

O. Luminet, Toronto, Ont., Canada

M.A. Lumley, Detroit, Mich., USA

U. Lundberg, Lund, Sweden

A. MacLeod, Egham, UK

L. Mangelli, Isleworth, UK

B. Mangweth, Innsbruck, Austria

L.S. Mann, Falls Church, Va., USA

P. Manu, Glen Oaks, N.Y., USA

B. Miller, Buffalo, N.Y., USA

I. Moilanen, Oulu, Finland

R. Mota Cardoso, Porto, Portugal

C.I. Mulder, Rotterdam, The Netherlands

E. Neidhardt, Marburg, Germany

E.R.S. Nijernhuis, Amsterdam, The Netherlands

R. Novaco, Irvine, Calif., USA
M. Otto, Boston, Mass., USA

F. Ottolini, Cambridge, UK

C. Pariante, London, UK

J. Pennebaker, Austin, Tex., USA

G. Perini, Padova, Italy

A. Persky, Huddinge, Sweden

M. Piccinelli, Verona, Italy

P. Porcelli, Castellana Grotte, Italy

M. Probst, Kortenberg, Belgium

B. Radanov, Bern, Switzerland

C. Rafanelli, Bologna, Italy

A.R. Raffi, Bologna, Italy

C. Ruini, Cambridge, UK

C.D. Ryff, Madison, Wisc., USA

E. Sanavio, Padova, Italy

G.M. Simpson, Los Angeles, Calif., USA

N. Sonino, Padova, Italy

H. Speidel, Kiel, Germany

L.V. Sturges, Pomona, Calif., USA

E. Tomba, Bologna, Italy

J. Treasure, London, UK

M. Weinryb, Stockholm, Sweden

M. Weitzner, Tampa, Fla., USA

C. Zimmermann, Verona, Italy

\section{KARGER \\ Fax + 41613061234 \\ E-Mailkarger@karger.ch \\ www.karger.com \\ (c) 1999 S. Karger AG, Basel \\ 0033-3190/99/0682-0057\$17.50/0 \\ Accessible online at: \\ http://BioMedNet.com/karger}


Fig. 1. Impact factors of leading psychosomatic journals (1991-1997).

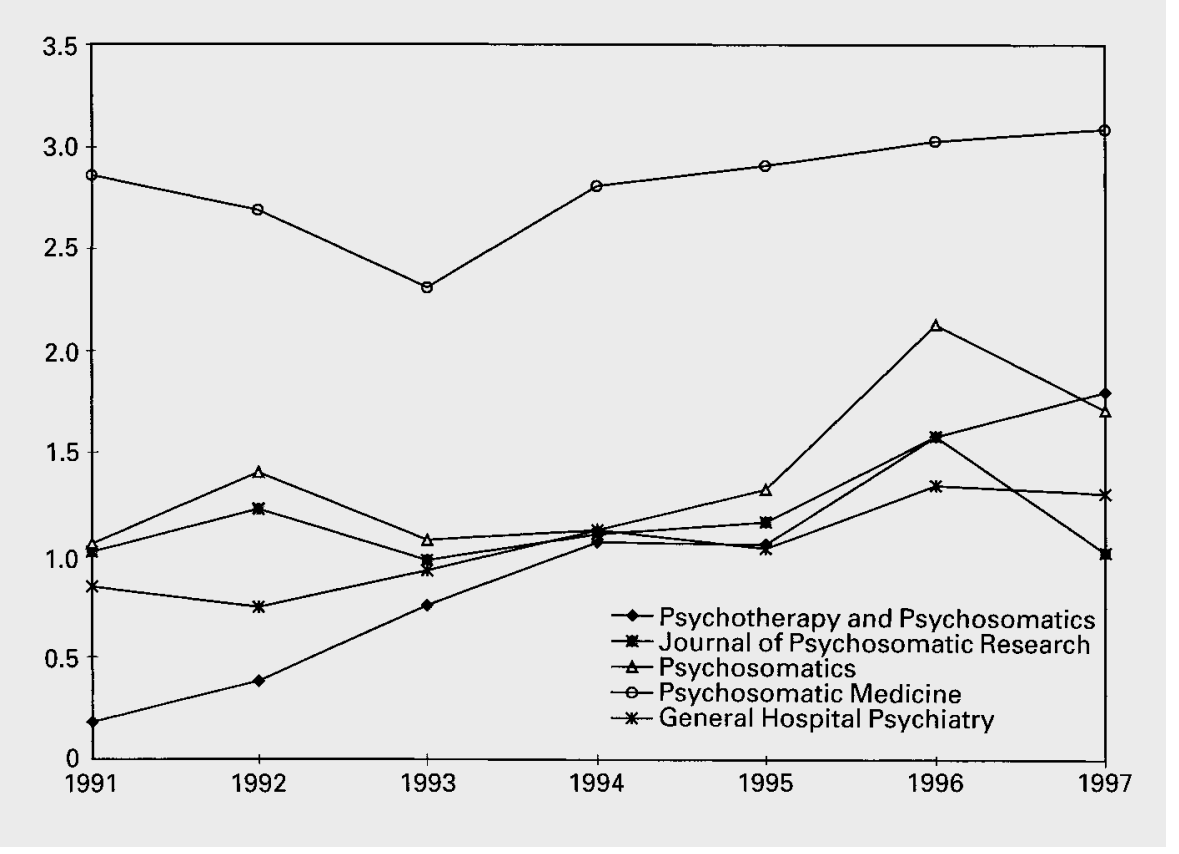

any conflict of interest (both in terms of financial ties with the products under discussion and of competitive research). It is important to emphasize that we ask our external reviewers and members of the editorial board to review the papers also in the presence of a substantial conflict of interest. We believe, in fact, that despite this, reviewers are capable of performing a balanced review. Simply, we want to be informed about potential conflicts of interest. This is a policy which is in line with our position on conflict of interest [1], but that - unfortunately has attracted a very limited attention as a source of bias [2]. Financial conflicts of interest are not the only source of bias: academic and personal rivalries may be as or more dangerous [3]. Regrettably, all attention on the peer review process seems to be focused on the minor issue of masking and blinding [4]. A recent discussion about the review process of a multicenter trial highlights this prob- lem [5]. As a result, disclosure of conflict of interest is a requirement for both submitting authors and reviewers of this journal. It is hoped that our policy is also endorsed by other journals.

\section{References}

Fava GA: All our dreams ares sold. Psychother Psychosom 1998;67:191-193.

2 Ellis SJ: Peer review and conflicts of interest. J Intern Med 1995;237:219-220.

3 Horton R: Conflicts of interest in clinical research: Opprobrium or obsession? Lancet 1998;349:1112-1113.

4 Davidoff F: Masking, blinding, and peer review: The blind leading the blinded. Ann Intern Med 1998;128:66-68.

5 Capehart BP, Holsinger T: Olanzapine on trial (letter to the editor). Am J Psychiatry 1998; 155:152. 